\title{
Visible Light Photoelectrocatalytic Degradation of Rhodamine B Using $\mathrm{Ti} / \mathrm{TiO}_{2}$-NiO Photoanode
}

\author{
Sayekti Wahyuningsih, Candra Purnawan, Teguh Endah Saraswati, Edi Pramono, \\ Ari Handono Ramelan, Setyo Pramono, Ari Wisnugroho \\ Inorganic Material Research Group, Department of Chemistry, Faculty Mathematics and Natural Science, \\ Sebelas Maret University, Surakarta, Indonesia \\ Email: sayekti@mipa.uns.ac.id
}

Received 22 September 2014; revised 18 October 2014; accepted 12 November 2014

Copyright @ 2014 by authors and Scientific Research Publishing Inc.

This work is licensed under the Creative Commons Attribution International License (CC BY). http://creativecommons.org/licenses/by/4.0/

c) (i) Open Access

\section{Abstract}

The method of $\mathrm{Ti} / \mathrm{TiO}_{2}$-NiO photoelectrode prepared by using sol-gel method continued by calcination process was introduced. The prepared $\mathrm{TiO}_{2}-\mathrm{NiO}$ film was observed with XRD and TEM. The anatase-rutile $\mathrm{TiO}_{2}$ was mainly on the prepared $\mathrm{TiO}_{2}-\mathrm{NiO}$ composite surface electrode. In addition to $\mathrm{NiO}$, the composite also formed $\mathrm{NiTiO}_{3}$ that increased with increasing calcination temperature. Photoelectrocatalytic degradation of Rhodamine B (RB) using this electrode was investigated, and anodic potential and $\mathrm{pH}$ were optimized. $\mathrm{RB}$ degradation was investigated under different conditions, and it showed that photoelectrocatalytic degradation could achieve efficient and complete mineralization of organic pollutant. Through comparison of the photoelectrocatalytic oxidation using the $\mathrm{Ti} / \mathrm{TiO}_{2}-\mathrm{NiO}$ electrode operated by single photoanode with the $\mathrm{Ti} / \mathrm{TiO}_{2}-\mathrm{NiO}$ electrode operated by several photoanode, it was found that the photoelectrocatalytic efficiency of that by series photoanodes was higher. Additionally, photoelectrocatalytic system was performed at the several different photoelectrodes, which verified the higher photocatalytic activity compared with the single photoelectrode.

\section{Keywords}

$\mathrm{Ti} \mathrm{TiO}_{2}$-NiO Photoelectrode, Visible Light, Photoelectrocatalysis Degradation, Rhodamine B

\section{Introduction}

Titanium dioxide $\left(\mathrm{TiO}_{2}\right)$ was widely used in photocatalytic degradation of the organic pollutants that could not

How to cite this paper: Wahyuningsih, S., Purnawan, C., Saraswati, T.E., Pramono, E., Ramelan, A.H., Pramono, S. and Wisnugroho, A. (2014) Visible Light Photoelectrocatalytic Degradation of Rhodamine B Using Ti/TiO $2-\mathrm{NiO}$ Photoanode. Journal of Environmental Protection, 5, 1630-1640. http://dx.doi.org/10.4236/jep.2014.517154 
be degraded easily such as dyes because of its favorable physical, chemical and photocatalytic properties and high stability [1]-[8]. This photocatalytic method was based on the reactive properties of photogenerated electron-hole pairs. They were generated in the semiconductor $\left(\mathrm{TiO}_{2}\right)$ particles under irradiation at suitable wavelengths $(\lambda \leq 400 \mathrm{~nm})$. These electrons and holes could also recombine. Since the hole was a powerful oxidizing agent, it could decompose contaminants adsorbed on the $\mathrm{TiO}_{2}$ surface. Meanwhile, it could also oxidize water to produce hydroxyl radicals that could decompose organic pollutants in water [9]-[12]. There were many reports on photoelectrocatalytic degradation of organic pollutants by using $\mathrm{TiO}_{2}$ electrodes which were prepared by coating the surfaces of electrically conducting sub-strates (ITO, Ti) with $\mathrm{TiO}_{2}$ film. In this method, positive potential was applied on the working electrode $\left(\mathrm{Ti} / \mathrm{TiO}_{2}\right.$ electrode), which could inhibit the recombination of electrons and holes and enhance the efficiency of photocatalytic degradation of organic compounds [5] [6] [13]-[18].

In order to improve the photoelectrocatalytic capability of $\mathrm{TiO}_{2}$ film, preparation of $\mathrm{TiO}_{2}$ film was extensively studied. $\mathrm{TiO}_{2}$ films were often prepared by using either sol-gel method [19]-[25], pray pyrolysis [26] or sputtering [27]. Metal oxides, such as $\mathrm{CuO}, \mathrm{Cu}_{2} \mathrm{O}, \mathrm{Fe}_{2} \mathrm{O}_{3}, \mathrm{WO}_{3}, \mathrm{MoO}_{3}, \mathrm{ZnO}, \mathrm{NiO}, \mathrm{SnO}_{2}$, and so on, have been considered for band-gap engineering of $\mathrm{TiO}_{2}$ as these oxides have compatible processing strategies with $\mathrm{TiO}_{2}$ [28]-[37]. Among these oxides, low band-gap $\mathrm{CuO}$ or $\mathrm{NiO}$ is used as sensitizers to use visible radiation, whereas other large band-gap oxides (e.g., $\mathrm{ZnO}, \mathrm{SnO}_{2}$ ) are coupled with $\mathrm{TiO}_{2}$ for extrinsic trapping of photogenerated charge carriers to enhance photoactivity. Among these, coupling $\mathrm{TiO}_{2}$ with $\mathrm{NiO}$ still attracts less attention. The band gaps of $\mathrm{SnO}_{2}$ and $\mathrm{TiO}_{2}$ are 3.80 and $3.2 \mathrm{eV}$ [38], respectively, and the $\mathrm{CB}$ edge of $\mathrm{NiO}$ is $0.5 \mathrm{~V}$ above that of $\mathrm{TiO}_{2}$ [39]. When the two semiconductor particles are coupled, the CB of $\mathrm{NiO}$ acts as a sink for photogenerated electrons. Since the photogenerated holes move in the opposite direction, they accumulate in the VB of the $\mathrm{TiO}_{2}$ particle, which increases the efficiency of charge separation.

In this paper, $\mathrm{Ti} / \mathrm{TiO}_{2}-\mathrm{NiO}$ electrode was prepared by using sol-gel method. The crystalline structure and surface morphology of $\mathrm{TiO}_{2}$ film were evaluated by using X-ray diffraction (XRD) and TEM. The effect of crystalline size and structure was discussed. The photoelectrocatalytic ability of this electrode for degradation of Rhodamine $\mathrm{B}(\mathrm{RB})$ (Figure 1) and the effect of anodic potential and $\mathrm{pH}$ on this photoelectrocatalytic reaction were investigated. The photoelectrocatalytic oxidation using the $\mathrm{Ti} / \mathrm{TiO}_{2}-\mathrm{NiO}$ electrode calcinated by furnace was compared. Additionally, photoelectrocatalytic oxidation measurements were performed at the variously counter electrodes of $\mathrm{Ti}$ (commercial), $\mathrm{Ti} / \mathrm{TiO}_{2}$, which indicated the higher photocatalytic activity of the $\mathrm{Ti} / \mathrm{TiO}_{2}$ electrode further.

The mechanism of the RB photodegradation may include the following possible steps [40]:

$$
\begin{gathered}
\mathrm{RB}+\mathrm{O}_{2}^{-\bullet} \longrightarrow 2 \text { rhodamine } \longrightarrow \text { products } \\
\mathrm{RB}+\mathrm{TiO}_{2}\left(\mathrm{e}^{-}\right) \longrightarrow 2 \text { rhodamine } \longrightarrow \text { products } \\
\mathrm{RB}+\mathrm{OH}^{\bullet} \longrightarrow \mathrm{RB}^{+\bullet}+\mathrm{OH}^{-} \\
\mathrm{RB}^{+\bullet}+\mathrm{O}_{2}^{-\bullet} \longrightarrow 2 \text { rhodamine } \longrightarrow \text { products }
\end{gathered}
$$

The cationic dye radical of RB is degraded into carbon dioxide, water, and mineral acids through a rhodamine intermediate. The rhodamine intermediate could be detected by UV-VIS spectroscopy from approximately 240 $\mathrm{nm}$ to $360 \mathrm{~nm}$. In principle, the degradation process of RB decreases the absorption peak at $543 \mathrm{~nm}$, but increases absorption peaks at approximately $240-360 \mathrm{~nm}$. Qu et al. (1998) [28] reported that $\mathrm{OOH}^{*}$ and $\mathrm{OH}^{*}$ are necessary for the $N$-de-ethylation of RB, which, in turn, is necessary for complete degradation of the dye.

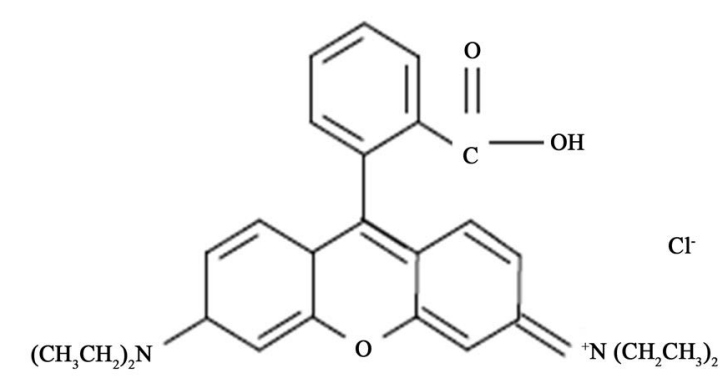

Figure 1. Structure of Rhodamine B. 


\section{Experiment}

\subsection{Reagent}

Titanium (99.7\%, in area $10 \mathrm{~cm} \times 3 \mathrm{~cm}$ ) was purchased from the Far East Ti Equipment Co., Shanghai, China. RB, titanium tetraisopropoxide (TTIP), ethanol, acetic acid, nickel chloride and other chemical reagents were purchased from E. Merck (Indonesia). All reagents were of analytical reagent grade quality. All solutions were prepared with doubly distilled water.

\subsection{Device}

X-ray data were collected by using a D8ADVANCE X-ray diffractometer (Bruker axs Co., Germany) based on $\mathrm{CuK} \alpha$ radiation. The $2 \theta$ (two-theta) angle of the diffractometer was stepped from $10^{\circ}$ to $80^{\circ}$ by $0.03^{\circ}$ increments. Transmission Electron microscope (TEM) was obtained by a JOEL JEM 1400 (Japan) with an in-column energy filter. Electrochemical experiments were performed with a Potentiostat (Jiangsu Electroanalytical Co., China). The two electrode system consisted of a $\mathrm{Ti} / \mathrm{TiO}_{2}-\mathrm{NiO}$ electrode as the working electrode, electrode and a $\mathrm{Ti} / \mathrm{TiO}_{2}$ as the counter electrode. The radiation source was a halogen lamp ( $300 \mathrm{~W}$, Osram).

\section{3. $\mathrm{TiO}_{2}$ Film Preparation}

The $\mathrm{TiO}_{2}$ film has been synthesized by procedures that have been published previously [40]. A $10 \mathrm{~mL}$ solution of TTIP was hydrolysed in the $100 \mathrm{~mL}$ acetic acid glacial solution and mixed under vigorous stirring in an ice water-bath $\left(10^{\circ} \mathrm{C}-15^{\circ} \mathrm{C}\right)$ until a clear yellow solution of $\mathrm{TiO}_{2}$ nanocrystals was formed. The solution was heated at $90^{\circ} \mathrm{C}$ for $2 \mathrm{~h}$ when it became a gel, which was then placed in an oven at $150^{\circ} \mathrm{C}$ for $24 \mathrm{~h}$ to undergo an aging process. Next, the $\mathrm{TiO}_{2}$ xerogel was ground and pulverized into a fine powder and calcined in a muffle furnace at $400^{\circ} \mathrm{C}$ for $2 \mathrm{~h}$ at a heating rate of $10^{\circ} \mathrm{C} \cdot \mathrm{min}^{-1}$. Then, ethanol was added to the $\mathrm{TiO}_{2}$ powder before dip-coating to the Ti mesh. The $\mathrm{TiO}_{2}$-coated Ti mesh was then dried at $100^{\circ} \mathrm{C}$ for $5 \mathrm{~min}$. The coating and drying treatments was repeated three times.

\section{4. $\mathrm{TiO}_{2}$-NiO Films Preparation}

1.145 grams of synthesized xerogel $\mathrm{TiO}_{2}$ (previous procedure) was added in 0.81 grams of $\mathrm{NiNO}_{3} \cdot 6 \mathrm{H}_{2} \mathrm{O}$ that has dissolved in $25 \mathrm{ml}$ of distilled water. The mixed solution was stirred with magnetic stirrer to fuse. Then, the uniform mixture was dried at $110^{\circ} \mathrm{C}$ for $3 \mathrm{~h}$. To improve the crystalline $\mathrm{TiO}_{2}-\mathrm{NiO}$ after the green suspension was formed, it was calcinated at various temperature of $150^{\circ} \mathrm{C}, 300^{\circ} \mathrm{C}, 400^{\circ} \mathrm{C}, 500^{\circ} \mathrm{C}, 600^{\circ} \mathrm{C}$, and $700^{\circ} \mathrm{C}$ for 4 hours at $10^{\circ} \mathrm{C} / \mathrm{min}$. The crystalline $\mathrm{TiO}_{2}-\mathrm{NiO}$ composite was superimposed onto a $\mathrm{SnO}_{2} \mathrm{~F}$ conductive glass and was dried at $110^{\circ} \mathrm{C}$ for $3 \mathrm{~h}$. The coating and drying treatments was repeated three times.

\subsection{Photoelectrodegradation Experiment}

In order to investigate the photoelectrocatalytic (PEC) activity of the prepared sensitized $\mathrm{TiO}_{2}$ thin film, a series of degradation experiments of Rhodamine $\mathrm{B}$ in aqueous solutions were performed. The initial concentration of Rhodamine B was $5 \mathrm{mg} \cdot \mathrm{L}^{-1}$, with $0.05 \mathrm{~mol} \cdot \mathrm{L}^{-1}$ of $\mathrm{NaCl}$ used as the supporting electrolyte. The total volume of the solution was $10 \mathrm{~mL}$. Experiments were carried out in an optical quality quartz cell equipped with a twoelectrode system. A copper wire as well as Ti plate was used as the counter electrode. The front of the working electrode was irradiated with a $300 \mathrm{~W}$ visible light lamp (Halogen lamp, Osram) and the progress of the photoelectrocatalytic degradation was recorded at defined intervals by UV-VIS spectroscopy. The PEC degradation of $\mathrm{RB}$ was performed at voltages of $1.0 \mathrm{~V}$ to $+10.0 \mathrm{~V}$ and at various $\mathrm{pH}$ values.

\section{Results and Discussions}

\subsection{The Characteristics of $\mathrm{TiO}_{2}$ Film}

The $\mathrm{TiO}_{2}$ films prepared by sol-gel from titanium tetraisopropoxide precursor were characterized by XRD, as shown in Figure 2. The present work, the sol-gel method was carried out under acidic conditions with acetic acid as solvent. The use of acetic acid as the solvent, as well as activating the formation of $\mathrm{Ti}\left(\mathrm{OCOCH}_{3}\right)\left(\mathrm{O}^{i} \mathrm{Pr}\right)_{2}$ complexes, permits control of both the degree of condensation and the oligomerisation and induces preferential 


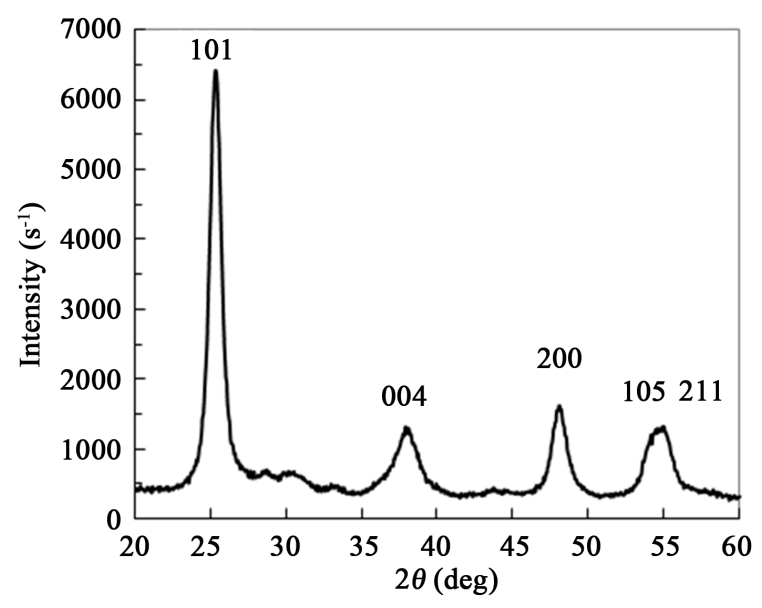

Figure 2. XRD pattern of prepared anatase $\mathrm{TiO}_{2}$.

crystallisation of $\mathrm{TiO}_{2}$ in the anatase phase. In the first case, a spherical and relatively monodisperse aggregates of nanocrystallites could be obtained. The growth kinetics of the aggregates is determined by the stability of the colloid. The $\mathrm{TiO}_{2}$ particles formed are relatively stable and a white suspension is gradually formed due to the precipitation of large aggregates.

However, under the acetic acid conditions using the $\mathrm{Ti}\left(\mathrm{O}^{i} \mathrm{Pr}\right)_{4}$ precursor, the complexes formation was occur as described in the equation below [40].

$$
\mathrm{CH}_{3} \mathrm{COO}^{-}+\mathrm{Ti}\left(\mathrm{O}^{i} \mathrm{Pr}\right)_{4} \stackrel{\mathrm{H}^{+}}{\longrightarrow} \mathrm{Ti}\left(\mathrm{OCOCH}_{3}\right)\left(\mathrm{O}^{i} \mathrm{Pr}\right)_{2}
$$

In further hydrolysis and condensation steps, the $\mathrm{Ti}\left(\mathrm{OCOCH}_{3}\right)\left(\mathrm{O}^{i} \mathrm{Pr}\right)_{2}$ product will produce nanotitania. In this research, nano- $\mathrm{TiO}_{2}$ was prepared from stock solutions of $110 \mathrm{~mL}$ solution containing titanium tetraisopropoxide and acetic acid solution in a volume ratio of $1: 10$ in a water bath $\left(10^{\circ} \mathrm{C}-15^{\circ} \mathrm{C}\right)$. The anatase of $\mathrm{TiO}_{2}$ was obtained after an annealing process at $400^{\circ} \mathrm{C}$ (annealing rate of $10^{\circ} \mathrm{C}$ min). Figure 2 shows that the XRD pattern of the $\mathrm{TiO}_{2}$ thus prepared exhibits strong diffraction peaks at $2 \theta=25.35^{\circ}\left(d_{101}=3.51 \AA\right), 2 \theta=37.90^{\circ}\left(d_{004}=2.37\right.$ $\AA), 2 \theta=48.11^{\circ}\left(d_{200}=1.89 \AA\right), 2 \theta=54.16^{\circ}\left(d_{105}=1.69 \AA\right)$, and $2 \theta=54.96^{\circ}\left(d_{211}=1.67 \AA\right)$, indicating that $\mathrm{TiO}_{2}$ is formed by the anatase phase. All peaks are in good agreement with the standard spectrum (JCPDS No.: JCPDS \# 782-484). This result suggested that the nano- $\mathrm{TiO}_{2}$ powder was irregularly polycrystalline. The XDR pattern shows that only the anatase phase is formed.

In addition, TEM was used to further examine the crystallite/particle size, crystallinity, and morphology of the samples. Clear spherical and non-homogeneous structures can be seen in Figure 3(a), with the average size of the primary particle approximately $10 \mathrm{~nm}$, which is in good agreement with the value determined by XRD. The particle of $\mathrm{TiO}_{2}$ in the anatase phase has a mostly spherical morphology (Figure 2(a)). The area selected for electron diffraction pattern analysis (SAED), confirming that the $\mathrm{TiO}_{2}$ nanoparticles are highly crystalline in the anatase phase, in good agreement with the standard JCPDS \# 782-484 and XRD result.

\subsection{The Characteristics of $\mathrm{TiO}_{2}-\mathrm{NiO}$ Film}

The composite of $\mathrm{TiO}_{2}-\mathrm{NiO}$ was obtained after an annealing process at $700^{\circ} \mathrm{C}$ (annealing rate of $10^{\circ} \mathrm{C}$ min). Figure 4 shows that the XRD pattern of the $\mathrm{TiO}_{2}-\mathrm{NiO}$ thus prepared exhibits strong diffraction peaks at $2 \theta=$ $27.45^{\circ}\left(d_{110}=3.2452 \AA\right), 2 \theta=36.10^{\circ}\left(d_{101}=2.4849 \AA\right), 2 \theta=39.20^{\circ}\left(d_{200}=2.2952 \AA\right), 2 \theta=41.25^{\circ}\left(d_{111}=\right.$ $2.1858 \AA), 2 \theta=44.05^{\circ}\left(d_{210}=2.0531 \AA\right), 2 \theta=54.36^{\circ}\left(d_{211}=1.6858\right)$, and $2 \theta=56.66^{\circ}\left(d_{220}=1.6227 \AA\right)$ which are the characterization of rutile $\mathrm{TiO}_{2}$ according to the standard JCPDS No. 870-710. There are also several peaks indicates the anatase phase at $2 \theta=25.40^{\circ}\left(d_{101}=3.5023 \AA\right), 2 \theta=37.90^{\circ}\left(d_{004}=2.3709 \AA\right)$, and $2 \theta=$ $48.15^{\circ}\left(d_{200}=1.8874 \AA\right)$ according to the standard JCPDS No. 782-486. Peaks characteristic of $\mathrm{NiTiO}_{3}$ are peaks at the $2 \theta=24^{\circ}\left(\mathrm{d}_{012}=3.6584 \AA\right), 2 \theta=33^{\circ}\left(\mathrm{d}_{110}=2.6911 \AA\right), 2 \theta=49^{\circ}\left(\mathrm{d}_{024}=1.8356 \AA\right)$, and $2 \theta=57^{\circ}$ $\left(\mathrm{d}_{018}=1.5969 \AA\right)$. All peaks are in good agreement with the standard spectrums JCPDS No. 753-757.

TEM was used to further examine the crystallite/particle size, and morphology of the $\mathrm{TiO}_{2}-\mathrm{NiO}_{\text {composites }}$ samples. Clear spherical and non-homogeneous structures can be seen in Figure 5(a), with the average size of 

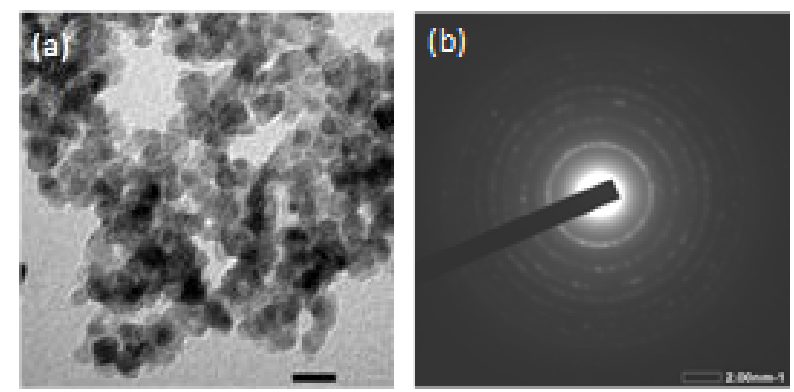

Figure 3. Images of anatase phase. (a) TEM image of nano- $\mathrm{TiO}_{2}$ powder; (b) SAED pattern of nano- $\mathrm{TiO}_{2}$ powde.

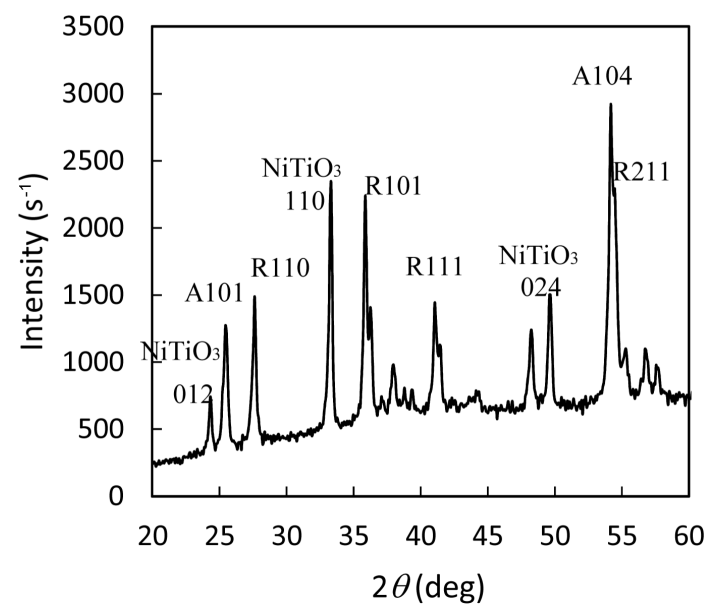

Figure 4. XRD pattern of $\mathrm{TiO}_{2}-\mathrm{NiO}$ thin film.
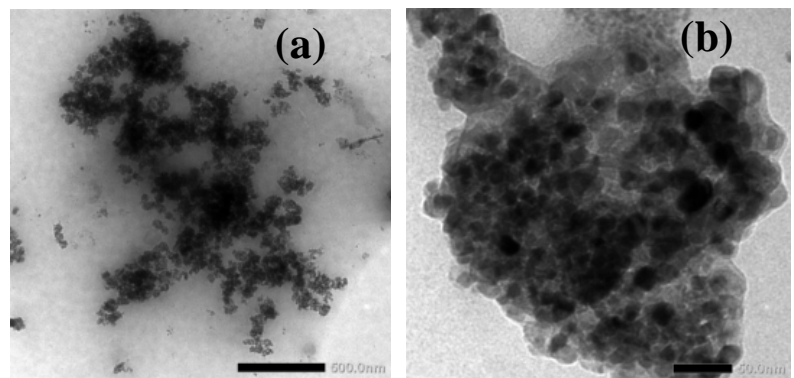

Figure 5. TEM Image of $\mathrm{TiO}_{2}-\mathrm{NiO}$ nanoparticle were used for photoanode preparation (a) $500 \mathrm{~nm}$ bar; (b) $50 \mathrm{~nm}$ bar.

the primary particle approximately $20-30 \mathrm{~nm}$, which is in good agreement with the value determined by XRD. The particle of $\mathrm{TiO}_{2}$ in the anatase phase has a mostly spherical morphology (Figure 5(a)). The area selected for electron diffraction pattern analysis (SAED) (Figure 5(b)), confirming that the $\mathrm{TiO}_{2}-\mathrm{NiO}$ nanoparticles are also highly crystalline in the anatase phase, rutile phase and $\mathrm{TiNiO}_{3}$.

While the part of photoanoda $\mathrm{TiO}_{2}-\mathrm{NiO}$ composite shows that $\mathrm{TiO}_{2}-\mathrm{NiO}$ materials were deposited on the $\mathrm{Ti}$ contained on porous amorphous silica (Figure 6). The conductivity character of those composite is shown in Figure 7. The profile shows that the composite photoanoda $\mathrm{Ti} / \mathrm{TiO}_{2}-\mathrm{NiO}$ quite well as electron generation. Based on the bar graph in Figure 8, that shows the percentage of formation of $\mathrm{NiO}$ in a variety of temperatures, as well as the byproducts $\mathrm{NiTiO}_{3}$. $\mathrm{NiTiO}_{3}$ arises due to the formation of $\mathrm{NiO}$ and $\mathrm{TiO}_{2}$. Percentage of $\mathrm{NiO}$ in the composite achieving optimum condition at $500^{\circ} \mathrm{C}$ reached $22.78 \%$. Another product is a composite of $\mathrm{NiTiO}_{3}$ that appears on composite roasted at $600^{\circ} \mathrm{C}$ and roasted at $700^{\circ} \mathrm{C}$ composite. Increased temperature and addition of $\mathrm{NiO}$ dopants were affecting the $\mathrm{TiO}_{2}$ crystalization. Increased temperature and the addition of $\mathrm{NiO}$ dopants 


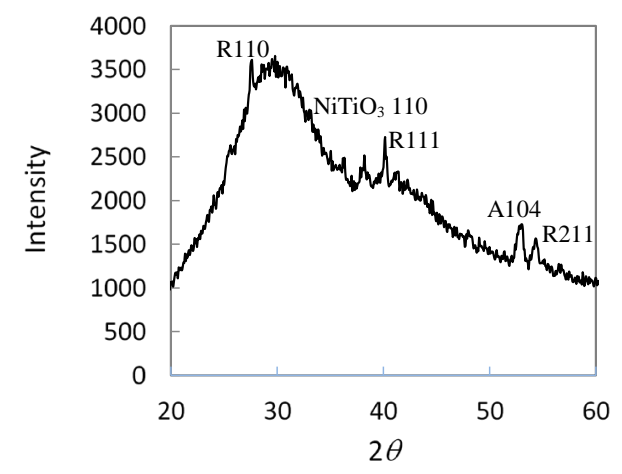

Figure 6. XRD Pattern of $\mathrm{Ti} / \mathrm{TiO}_{2}-\mathrm{NiO}$ electrode material.

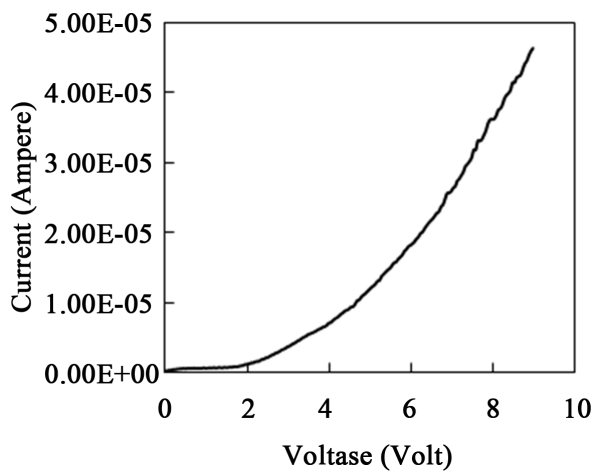

Figure 7. Voltage applied-current profile of the $\mathrm{Ti} / \mathrm{TiO}_{2}-\mathrm{NiO}$ electrode. Counter electrode: $\mathrm{Ti} / \mathrm{TiO}_{2}$ electrode.

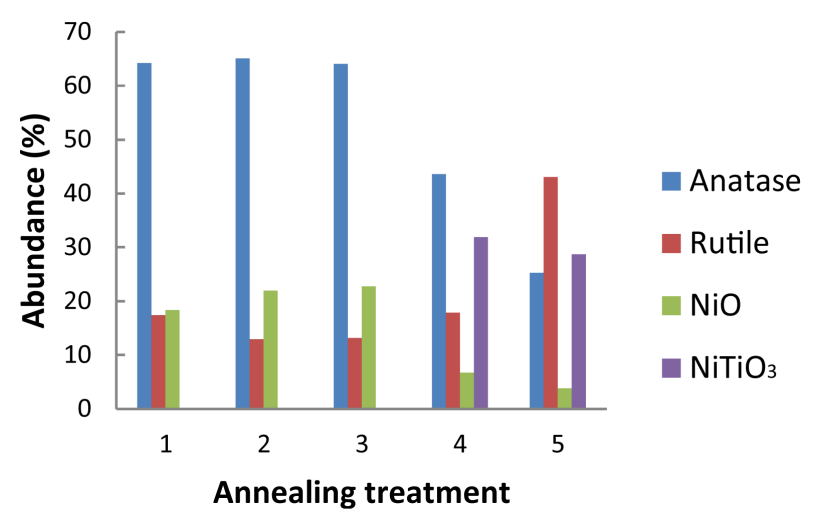

Figure 8. Relative abundance of anatase phase, rutile phase, $\mathrm{NiO}$, and $\mathrm{NiTiO}_{3}$ on $\mathrm{TiO}_{2}-\mathrm{NiO}$ composite result of annealing at $300^{\circ} \mathrm{C}(1), 400^{\circ} \mathrm{C}(2), 500^{\circ} \mathrm{C}(3), 600^{\circ} \mathrm{C}(4)$, and $700^{\circ} \mathrm{C}(5)$.

were affecting $\mathrm{TiO}_{2}$ crystal structure transformation. The addition of these dopants was found to suppress the transformation of anatase into rutile (compared with no addition of dopand, Table 1). The occurrence of these structural transformations will change the photoactivity of $\mathrm{TiO}_{2}$ and further explained in $\mathrm{TiO}_{2}-\mathrm{NiO}$ composite activity for photodegradation of Rhodamine B.

\subsection{Influence of $\mathrm{pH}$}

This experiment was carried out at different $\mathrm{pH}$ values of 2.0, 4.0, 6.0, 8.0 and 10.0, respectively, in order to investigate the process of RB photoelectrocatalytic degradation. The experimental results were shown in Figure 9. It demonstrated that the efficiency of the photoelectrode on the photoelectrocatalytic degradation of RB was 


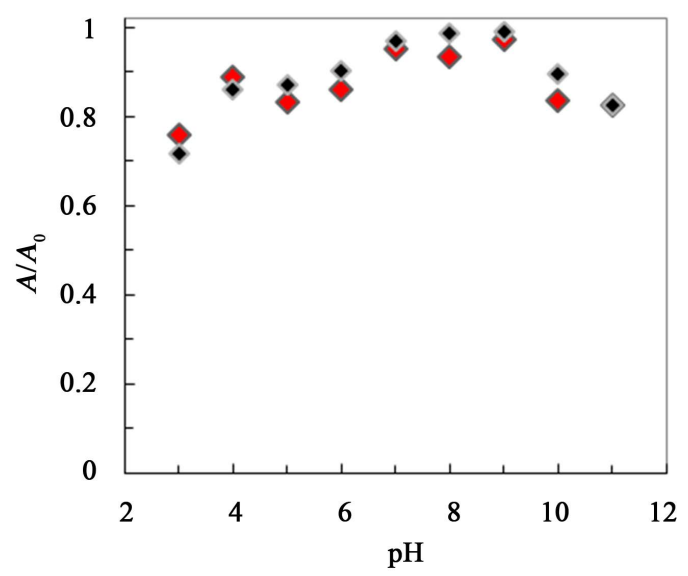

Figure 9. Absorbance of RB solution after photoelectrocatalytic degradation for $180 \mathrm{~min}$ at various $\mathrm{pH}$ values under visible light irradiation $\left([\mathrm{NaCl}]=0.05 \mathrm{M},[\mathrm{RB}]=5 \times 10^{-4}\right.$ mass $\%$, applied bias potential $1.0 \mathrm{~V})$.

Table 1. Anatase to rutile ratio (A/R) of the synthesized $\mathrm{TiO}_{2}$ and composite $\mathrm{TiO}_{2}-\mathrm{NiO}$.

\begin{tabular}{ccccccc}
\hline \multirow{2}{*}{$\mathrm{A} / \mathrm{R}$ ratio } & \multicolumn{5}{c}{ Annealing temperature } \\
\cline { 2 - 7 } & $150^{\circ} \mathrm{C}$ & $300^{\circ} \mathrm{C}$ & $400^{\circ} \mathrm{C}$ & $500^{\circ} \mathrm{C}$ & $600^{\circ} \mathrm{C}$ & $700^{\circ} \mathrm{C}$ \\
\hline $\mathrm{TiO}_{2}$ & $1: 0$ & $1: 0$ & $1: 0$ & $1: 0.06$ & $1: 0.72$ & $1: 9.93$ \\
$\mathrm{TiO}_{2}-\mathrm{NiO}$ composite & $1: 0$ & $1: 0.20$ & $1: 0.20$ & $1: 0.21$ & $1: 0.41$ & $1: 1.70$ \\
\hline
\end{tabular}

improved with the increase in $\mathrm{pH}$ value and the rate constant of the photoelectrocatalytic degradation of $\mathrm{RB}$ was also increased at the same time. The results showed that the photoelectrocatalytic activity of the photoelectrode was increased due to the increase in $\mathrm{pH}$ value. The study of the effect of $\mathrm{pH}$ value on the efficiency of photoelectrocatalytic degradation of organic dye was valuable but complicated. Firstly, $\mathrm{pH}$ value had significant effect on the absorption behavior of the organic dye on the catalyst surface. The point of zero charge of the $\mathrm{TiO}_{2}$ that was the catalyst was at $\mathrm{pH}$ 6.4. Thus, the $\mathrm{TiO}_{2}$ surface was positively charged in the media with $\mathrm{pH}$ less than 6.4, whereas it was negatively charged under the conditions with the $\mathrm{pH}$ greater than 6.4. The value of $\mathrm{pH}$ could also influence the charge carried by the molecule [40], the molecule of RB was cationic form at lower than 4 . When the $\mathrm{pH}$ value was less on the catalyst surface became difficult because of an electrostatic repulsive force. When the $\mathrm{pH}$ value was greater than 4, the molecule of $\mathrm{RB}$ was in the zwitterionic form and a certain part of the molecule was attracted by the catalyst surface due to the electrostatic attraction [16]. As a result, the efficiency of the photoelectrocatalytic degradation of RB was relatively low with the $\mathrm{pH}$ less than 4 while the efficiency was increased with the $\mathrm{pH}$ greater than 4 . Secondly, the change of $\mathrm{pH}$ had an important effect on modifying the position of the $\mathrm{TiO}_{2}$ conduction band (60 mV per pH unit) [35]. Thus, the oxidizing ability of photogenerated holes was raised, i.e. the hydroxyl radical production was facilitated in the oxidation of water (or hydroxide ions) by photogenerated holes. The more alkaline, the more readily water (or hydroxide ions) underwent oxidation to generate hydroxyl radicals on the catalyst surface. Therefore, the photoelectrocatalytic degradation of RB was more efficient due to the increase in $\mathrm{pH}$ value. The $\mathrm{pH}$ value of 10 was selected in subsequent experiments.

\subsection{Degradation of RB under Different Applied Potential Bias Conditions by the Proposed Photoelectrode}

When the potential was $3.0 \mathrm{~V}$, the rate of photoelectron transport process was lower and controlled the overall PEC oxidation. Thus, the photocurrent increased within the potential of $3.0-5.0 \mathrm{~V}$. Once the applied bias exceeded $5.0 \mathrm{~V}$, the interfacial oxidation, which was slower than the photoelectron transport, became the rate-determining step of the overall process. Under this condition the photocurrent saturated gradually. The anodic potential was an important parameter in the process of photoelectrocatalytic degradation of RB. The effect of applied potential was determined by using a series of potentials. To study the key factors affecting the photodegradation of RB, a series of tests were executed under different experimental conditions in which the deduction 
of Vis absorbance was estimated.

After 5 min degradation (batch system), about 96.3\% of RB was removed. Photoelectrocatalytic (PEC) experiment 1 was carried out under halogen lamp irradiation using the $\mathrm{Ti} / \mathrm{TiO}_{2}-\mathrm{NiO}$ photoelectrode with a potential voltage of $+10.0 \mathrm{~V}$. It was obvious that the degradation rate was very fast. But their applied potential voltages make the electrode surface damage rapidly. Furthermore, the continuous systems were done with applied potential bias of 4, 5, and 6 volts. The results are shown in Table 2. However, RB could not undergo complete degradation to produce $\mathrm{CO}_{2}$ and $\mathrm{H}_{2} \mathrm{O}$, as a result, the intermediates were produced during the process [40]. Therefore, PEC method showed high complete mineralization activity in the RB degradation reaction. Figure 10 shows no prominent peak in the UV region around $370 \mathrm{~nm}$ as an indication of an intermediate peak of rhodamine.

\subsection{Compared the Photoelectrocatalytic Oxidation Using Several Photoelectrodes}

Compared the photoelectrocatalytic oxidation using the $\mathrm{Ti} / \mathrm{TiO}_{2}$ electrode by batch system as well as by single photoanode (Table 2), the photoelectrocatalytic oxidation process using integrated photoanode can enhance the RB degradation, respectively, as shown in Table 3 . The experimental results also demonstrated that the reaction rate of RB degradation using several electrode by continuous system was higher than that by single photoanode.

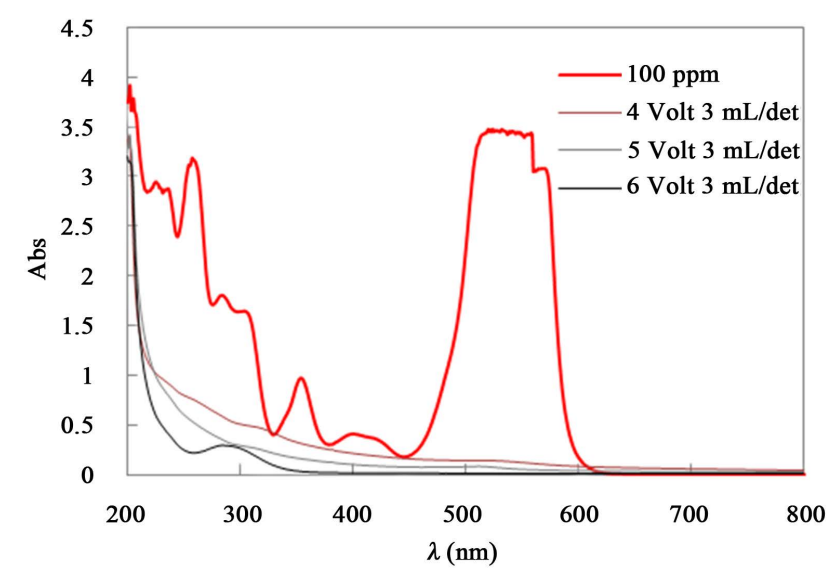

Figure 10. Electronic spectra of Rhodamine B before and after photoelectrocatalytic degradation process at a variation applied voltage.

Table 2. Degradation of RB (\%) under different experimental conditions using $\mathrm{Ti} / \mathrm{TiO}_{2}-\mathrm{NiO}$ photoanode with a 300 watts halogen lamp irradiation.

\begin{tabular}{ccccc}
\hline \multirow{2}{*}{ Experiment } & Potential voltage of photoanode (volt) & Batch system (\%) & \multicolumn{2}{c}{ Continuous system (\%) } \\
\cline { 3 - 5 } & 10 & $96.3^{*}$ & $3 \mathrm{~mL} / \mathrm{sec}$ & $6 \mathrm{~mL} / \mathrm{sec}$ \\
\hline 1 & 4 & & 10.0 & 14.9 \\
3 & 5 & 12.7 & 15.3 \\
4 & 6 & 15.9 & 16.3 \\
\hline
\end{tabular}

Table 3. Degradation of RB (\%) under different experimental conditions using several photoanode of $\mathrm{Ti} / \mathrm{TiO}_{2}$ $\mathrm{NiO}, \mathrm{Ti} / \mathrm{TiO}_{2}-\mathrm{PbO}, \mathrm{Ti} / \mathrm{Ta}-\mathrm{Ir}$ and $\mathrm{Ti} / \mathrm{Ru}-\mathrm{Ir}$ photoanodes, respectively, under a 300 watts halogen lamp irradiation.

\begin{tabular}{|c|c|c|}
\hline \multirow{2}{*}{ Applied bias potential of photoanode (volt) } & \multicolumn{2}{|c|}{ Flow rate } \\
\hline & $3 \mathrm{~mL} / \mathrm{sec}$ & $6 \mathrm{~mL} / \mathrm{sec}$ \\
\hline 4 & 98.0 & 95.5 \\
\hline 5 & 99.3 & 97.0 \\
\hline 6 & 99.6 & 98.0 \\
\hline
\end{tabular}




\section{Conclusion}

In this paper, the method of preparation $\mathrm{Ti} / \mathrm{TiO}_{2}$ photoelectrode was firstly presented. The anatase $\mathrm{TiO}_{2}$ was mainly on the prepared electrode surface. Photoanode of the $\mathrm{TiO}_{2}-\mathrm{NiO}$ composite synthesized by sol-gel method showed that the photoelectrocatalytic degradation ran very well. Photoelectrocatalytic degradation of RB using this electrode was investigated, and the operating conditions were optimized. $\mathrm{pH}$ and applied bias voltage affected the rate of photoelectrocatalytic degradation of Rhodamine B. By the comparison of the photoelectrocatalytic oxidation using the $\mathrm{Ti} / \mathrm{TiO}_{2} \mathrm{NiO}$ electrode operated by single photoanode and the $\mathrm{TiO}_{2} \mathrm{NiO}$ electrode operated by several photoanode, it was found that the photoelectrocatalytic efficiency of that by series photoanodes was higher. Additionally, photoelectrocatalytic system was performed at the several different photoelectrodes, which verified the higher photocatalytic activity of the single system-treated electrode further.

\section{Acknowledgements}

This work is supported by the STRANAS research program (Contract Number No. 6562/UN27.16/PN/2014) from Director of Higher Education Ministry of Education and Culture of Indonesia.

\section{References}

[1] Krýsa, J., Keppert, M., Waldner, G. and Jirkovský, J. (2005) Immobilized Particulate $\mathrm{TiO}_{2}$ Photocatalysts for Degradation of Organic Pollutants: Effect of Layer Thickness. Electrochimica Acta, 50, 5255-5260. http://dx.doi.org/10.1016/j.electacta.2005.01.054

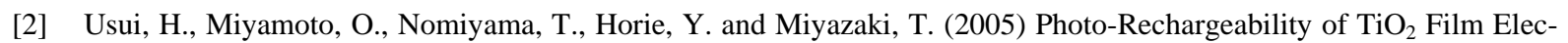
trodes Prepared by Pulsed Laser Deposition. Solar Energy Materials and Solar Cells, 86, 123. http://dx.doi.org/10.1016/j.solmat.2004.06.006

[3] Irmak, S., Kusvuran, E. and Erbatur, O. (2004) Degradation of 4-Chloro-2-Methylphenol in Aqueous Solution by UV Irradiation in the Presence of Titanium Dioxide. Applied Catalysis B: Environmental, 54, 85. http://dx.doi.org/10.1016/j.apcatb.2004.06.003

[4] Vinodgopal, K., Hotchandani, S. and Kamat, P.V. (1993) Electrochemically Assisted Photocatalysis: Titania Particulate Film Electrodes for Photocatalytic Degradation of 4-Chlorophenol. Journal of Physical Chemistry, 97, 9040. http://dx.doi.org/10.1021/j100137a033

[5] Osugi, M.E., Umbuzeiro, G.A., Anderson, M.A. and Zanoni, M.V.B. (2005) Degradation of Metallophtalocyanine Dye by Combined Processes of Electrochemistry and Photoelectrochemistry. Electrochimica Acta, 50, 5261. http://dx.doi.org/10.1016/j.electacta.2005.01.058

[6] Leng, W.H., Zhang, Z. and Zhang, J.Q. (2003) Photoelectrocatalytic Degradation of Aniline over Rutile $\mathrm{TiO}_{2} / \mathrm{Ti}_{\mathrm{Elec}}$ trode Thermally Formed at $600^{\circ} \mathrm{C}$. Journal of Molecular Catalysis A: Chemical, 206, 239. http://dx.doi.org/10.1016/S1381-1169(03)00373-X

[7] Ma, Y. and Yao, J.N. (1999) Comparison of Photodegradative Rate of Rhodamine B Assisted by Two Kinds of TiO Films. Chemosphere, 38, 2407. http://dx.doi.org/10.1016/S0045-6535(98)00434-2

[8] Wu, J.-M. and Zhang, T.-W. (2004) Photodegradation of Rhodamine B in Water Assisted by Titania Films Prepared through a Novel Procedure. Journal of Photochemistry and Photobiology A: Chemistry, 162, 171. http://dx.doi.org/10.1016/S1010-6030(03)00345-9

[9] Ishikawa, Y. and Matsumoto, Y. (2001) Electrodeposition of $\mathrm{TiO}_{2}$ Photocatalyst into Nano-Pores of Hard Alumite. Electrochimica Acta, 46, 2819. http://dx.doi.org/10.1016/S0013-4686(01)00490-X

[10] Kim, D.H. and Anderson, M.A. (1994) Photoelectrocatalytic Degradation of Formic Acid Using a Porous Titanium Dioxide Thin-Film Electrode. Environmental Science \& Technology, 28, 479. http://dx.doi.org/10.1021/es00052a021

[11] Konstantinou, I.K. and Albanis, T.A. (2004) $\mathrm{TiO}_{2}$-Assisted Photocatalytic Degradation of Azo Dyes in Aqueous Solution: Kinetic and Mechanistic Investigations. Applied Catalysis B: Environmental, 49, 1-14. http://dx.doi.org/10.1016/j.apcatb.2003.11.010

[12] Palombaria, R., Ranchellaa, M., Rola, C. and Sebastiani, G.V. (2002) Oxidative Photoelectrochemical Technology with $\mathrm{Ti} / \mathrm{TiO}_{2}$ Anodes. Solar Energy Materials and Solar Cells, 71, 359-368. http://dx.doi.org/10.1016/S0927-0248(01)00093-9

[13] Christensen, P.A., Curtis, T.P., Egerton, T.A., Kosa, S.A.M. and Tinlin, J.R. (2003) Photoelectrocatalytic and Photocatalytic Disinfection of E. coli Suspensions by Titanium Dioxide. Applied Catalysis B: Environmental, 41, 371-386. http://dx.doi.org/10.1016/S0926-3373(02)00172-8

[14] Li, X.Z., Li, F.B., Fan, C.M. and Sun, Y.P. (2002) Photoelectrocatalytic Degradation of Humic Acid in Aqueous 
Solution Using a Ti/TiO 2 Mesh Photoelectrode. Water Research, 36, 2215-2224.

http://dx.doi.org/10.1016/S0043-1354(01)00440-7

[15] Jiang, D., Zhao, H., Zhang, S. and John, R. (2004) Kinetic Study of Photocatalytic Oxidation of Adsorbed Carboxylic Acids at $\mathrm{TiO}_{2}$ Porous Films by Photoelectrolysis. Journal of Catalysis, 223, 212-220.

http://dx.doi.org/10.1016/j.jcat.2004.01.030

[16] Guo, Y., Zhao, J., Zhang, H., Yang, S., Qi, J., Wang, Z. and Xu, H. (2005) Use of Rice Husk-Based Porous Carbon for Adsorption of Rhodamine B from Aqueous Solutions. Dyes and Pigments, 66, 123-128. http://dx.doi.org/10.1016/j.dyepig.2004.09.014

[17] Chen, J., Liu, M., Zhang, L., Zhang, J. and Jin, L. (2003) Application of Nano $\mathrm{TiO}_{2}$ towards Polluted Water Treatment Combined with Electro-Photochemical Method. Water Research, 37, 3815-3820. http://dx.doi.org/10.1016/S0043-1354(03)00332-4

[18] Butterfield, I.M., Christensen, P.A., Curtis, T.P. and Gunlazuardi, J. (1997) Water Disinfection Using an Immobilised Titanium Dioxide Film in a Photochemical Reactor with Electric Field Enhancement. Water Research, 31, 675-677. http://dx.doi.org/10.1016/S0043-1354(96)00391-0

[19] Nazeeruddin, M.K., Kay, A., Rodicio, I., Humphry-Baker, R., Muller, E., Liska, P., Vlachopoulos, N. and Gratzel, M. (1993) Conversion of Light to Electricity by Cis-X2bis(2,2'-bipyridyl-4,4'-dicarboxylate)ruthenium(II) ChargeTransfer Sensitizers (X = Cl-, Br-, I-, CN-, and SCN-) on Nanocrystalline Titanium Dioxide Electrodes. Journal of the American Chemical Society, 115, 6382-6390. http://dx.doi.org/10.1021/ja00067a063

[20] Xu, Q. and Anderson, M.A. (1991) Synthesis of Porosity Controlled Ceramic Membranes. Journal of Materials Research, 6, 1073-1081. http://dx.doi.org/10.1557/JMR.1991.1073

[21] Trapalis, C.C., Karakassides, M.A., Kordas, G. and Aslanoglou, X. (1995) Study of a Multilayer Wavelength-Selective Reflector Prepared by the Sol-Gel Process. Materials Letters, 25, 265-269. http://dx.doi.org/10.1016/0167-577X(95)00183-2

[22] Dekany, I., Turi, L. and Kiraly, Z. (1999) CdS, $\mathrm{TiO}_{2}$ and $\mathrm{Pd}^{\circ}$ Nanoparticles Growing in the Interlamellar Space of Montmorillonite in Binary Liquids. Applied Clay Science, 15, 221-239. http://dx.doi.org/10.1016/S0169-1317(99)00016-2

[23] Kim, D.J., Oh, S.H. and Kim, E.J. (2002) Influence of Calcination Temperature on Structural and Optical Properties of $\mathrm{TiO}_{2}$ Thin Films Prepared by Sol-Gel Dip Coating. Materials Letters, 57, 355-360. http://dx.doi.org/10.1016/S0167-577X(02)00790-5

[24] Mogyorosi, K., Dekany, I. and Fendler, J.H. (2003) Preparation and Characterization of Clay Mineral Intercalated Titanium Dioxide Nanoparticles. Langmuir, 19, 2938-2946. http://dx.doi.org/10.1021/la025969a

[25] Li, J., Li, L., Zheng, L., Xian, Y. and Jin, L. (2006) Determination of Chemical Oxygen Demand Values by a Photocatalytic Oxidation Method Using Nano- $\mathrm{TiO}_{2}$ Film on Quartz. Talanta, 68, 765-770. http://dx.doi.org/10.1016/j.talanta.2005.06.012

[26] Golego, N., Studenikin, S.A. and Cocivera, M. (1999) Spray Pyrolysis Preparation of Porous Polycrystalline Thin Films of Titanium Dioxide Containing Li and Nb. Journal of Materials Research, 14, 698-707. http://dx.doi.org/10.1557/JMR.1999.0095

[27] Lee, C.E., Atkins, R.A. and Taylor, H.F. (1987) Reflectively Tapped Optical Fibre Transversal Filters. Electronics Letters, 23, 596-598. http://dx.doi.org/10.1049/el:19870428

[28] Qu, P., Zhao, J.C., Shen, T. and Hidaka, H. (1998) $\mathrm{TiO}_{2}$-Assisted Photodegradation of Dyes: A Study of Two 2 Competitive Primary Processes in the Degradation of $\mathrm{RB}$ in an Aqueous $\mathrm{TiO}_{2}$ Colloidal Solution. Journal of Molecular Catalysis A: Chemical, 129, 257-268. http://dx.doi.org/10.1016/S1381-1169(97)00185-4

[29] Papp, J., Soled, S., Dwight, K. and Wold, A. (1994) Surface Acidity and Photocatalytic Activity of $\mathrm{TiO}_{2}, \mathrm{WO}_{3} / \mathrm{TiO}_{2}$, and $\mathrm{MoO}_{3} / \mathrm{TiO}_{2}$ Photocatalysts. Chemistry of Materials, 6, 496-500. http://dx.doi.org/10.1021/cm00040a026

[30] Liao, D.L., Badour, C.A. and Liao, B.Q. (2008) Preparation of Nanosized $\mathrm{TiO}_{2} / \mathrm{ZnO}$ Composite Catalyst and Its Photocatalytic Activity for Degradation of Methyl Orange. Journal of Photochemistry and Photobiology A: Chemistry, 194, 11-19. http://dx.doi.org/10.1016/j.jphotochem.2007.07.008

[31] Kansal, S.K., Singh, M. and Sud, D. (2008) Studies on $\mathrm{TiO}_{2} / \mathrm{ZnO}$ Photocatalysed Degradation of Lignin. Journal of Hazardous Materials, 153, 412-417. http://dx.doi.org/10.1016/j.jhazmat.2007.08.091

[32] Jiang, Y., Sun, Y., Liu, H., Zhu, F. and Yin, H. (2008) Solar Photocatalytic Decolorization of C.I. Basic Blue 41 in an Aqueous Suspension of $\mathrm{TiO}_{2}$-ZnO. Dyes Pigments, 78, 77-83. http://dx.doi.org/10.1016/j.dyepig.2007.10.009

[33] Tada, H., Hattori, A., Tokihisa, Y., Imai, K., Tohge, N. and Ito, S. (2000) A Patterned- $\mathrm{TiO}_{2} / \mathrm{SnO}_{2}$ Bilayer Type Photocatalyst. The Journal of Physical Chemistry B, 104, 4585-4587. http://dx.doi.org/10.1021/jp000049r

[34] Liu, Z., Sun, D.D., Guo, P. and Leckie, J.O. (2007) An Efficient Bicomponent $\mathrm{TiO}_{2} / \mathrm{SnO}_{2}$ Nanofiber Photocatalyst Fabricated by Electrospinning with a Side-by-Side Dual Spinneret Method. Nano Letters, 7, 1081-1085. 
http://dx.doi.org/10.1021/nl061898e

[35] Kavan, L., Stoto, T., Gratzel, M., Fitzmaurice, D. and Shklover, V. (1993) Quantum Size Effects in Nanocrystalline Semiconducting Titania Layers Prepared by Anodic Oxidative Hydrolysis of Titanium Trichloride. Journal of Physical Chemistry, 97, 9493-9498. http://dx.doi.org/10.1021/j100139a038

[36] Lin, C.F., Wu, C.H. and Onn, Z.N. (2008) Degradation of 4-Chlorophenol in $\mathrm{TiO}_{2}, \mathrm{WO}_{3}, \mathrm{SnO}_{2}, \mathrm{TiO}_{2} / \mathrm{WO}_{3}$ and $\mathrm{TiO}_{2} / \mathrm{SnO}_{2}$ systems. Journal of Hazardous Materials, 154, 1033-1039. http://dx.doi.org/10.1016/j.jhazmat.2007.11.010

[37] Sreetawang, T., Suzuki, Y. and Yoshikawa, S. (2005) Photocatalytic Evolution of Hydrogen over Mesoporous $\mathrm{TiO}_{2}$ Supported NiO Photocatalyst Prepared by Single-Step Sol-Gel Process with Surfactant Template. International Journal of Hydrogen Energy, 30, 1053-1062. http://dx.doi.org/10.1016/j.ijhydene.2004.09.007

[38] Inoue, T., Akira, F., Satoshi, K. and Kenichi, H. (1979) Photoelectrocatalytic Reduction of Carbon Dioxide in Aqueous Suspensions of Semiconductor Powders. Nature, 277, 637-638. http://dx.doi.org/10.1038/277637a0

[39] Zhou, H., Qu, Y., Zeid, T. and Duan, X. (2012) Towards Highly Efficient Photocatalysts Using Semiconductor Nanoarchitectures. Energy \& Environmental Science, 5, 6732-6743. http://dx.doi.org/10.1039/c2ee03447f

[40] Wahyuningsih, S., Purnawan, C., Saraswati, T.E., Kartikasari, P.A. and Praistia, N. (2014) Visible Light Photoelectrocatalytic Degradation of Rhodamine B Using a Dye-Sensitised $\mathrm{TiO}_{2}$ Electrode. Chemical Papers, 68, 1248-1256. http://dx.doi.org/10.2478/s11696-013-0476-8 
Scientific Research Publishing (SCIRP) is one of the largest Open Access journal publishers. It is currently publishing more than 200 open access, online, peer-reviewed journals covering a wide range of academic disciplines. SCIRP serves the worldwide academic communities and contributes to the progress and application of science with its publication.

Other selected journals from SCIRP are listed as below. Submit your manuscript to us via either submit@scirp.org or Online Submission Portal.
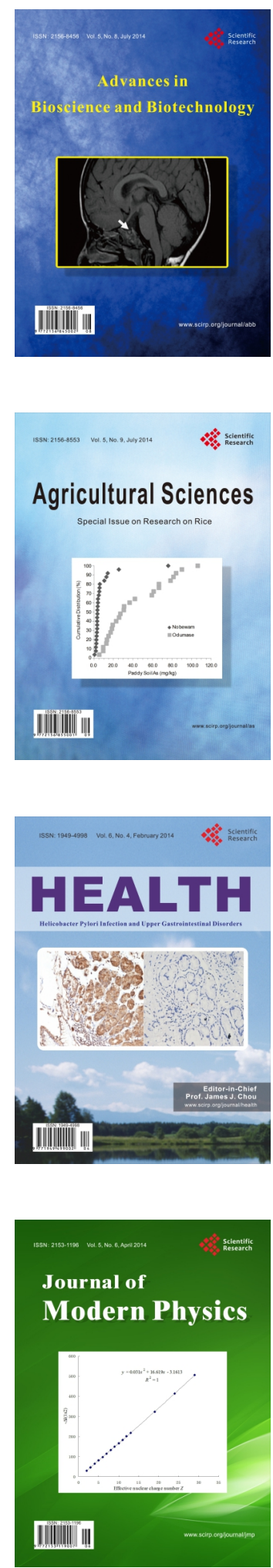
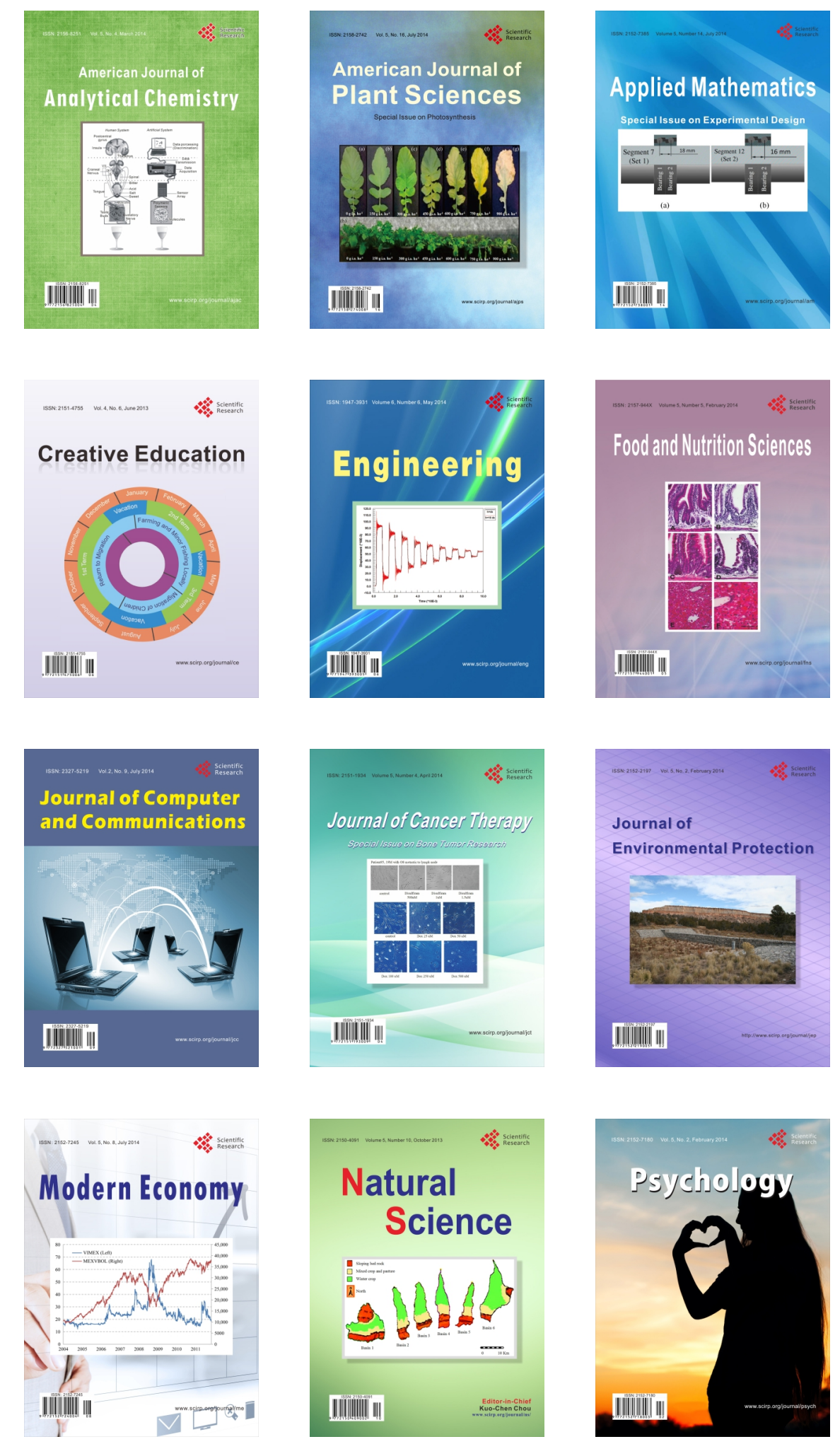